\title{
Peramalan Indeks Kekeringan Kelayang Menggunakan Metode Sarima dan SPI
}

\author{
Widdya Rahmalina ${ }^{1}$, Novreta ${ }^{2}$ \\ ${ }^{1}$ Program Studi Pendidikan Matematika, STKIP Adzkia, Padang 25153 \\ Email : widdyarahmalina@stkipadzkia.ac.id \\ ${ }^{2}$ Program Studi Budidaya Perairan Fakultas Perikanan dan Kelautan, Universitas Riau, Pekanbaru 28293 \\ Email : novreta@lecturer.unri.ac.id
}

\begin{abstract}
ABSTRAK
Kekeringan adalah salah satu bencana alam yang terjadi secara perlahan berlangsung lama hingga musim hujan tiba yang mempunyai dampak yang luas. Salah satu dampak kekeringan pada bidang pertanian pernah terjadi pada kabupaten Indragiri Hulu pada tahun 2015. Daerah irigasi (D.I) Kelayang merupakan daerah irigasi potensial yang mengairi wilayah pertanian di Kabupaten Indragiri Hulu. Untuk menanggulangi dampak kekeringan untuk masa yang akan datang perlu dilakukan peramalan indeks kekeringan. Indeks kekeringan sangat bergantung pada curah hujan. Untuk itu dilakukan peramalan curah hujan D.I Kelayang menggunakan metode Seasonal Autogressive Integrated Moving Average (SARIMA) karena diduga curah hujan merupakan data yang mengandung pola musiman. Kemudian dilakukan analisis indeks kekeringan menggunakan metode Standardized Precipitation Index (SPI). Hasil penelitian diperoleh model SARIMA $(2,0,1)(0,1,1)^{12}$ merupakan model yang layak digunakan untuk peramalan karena telah melewati uji ke-random-an dan kenormalan residual dengan mean squared dari residual yang terkecil yakni 4111,51. Setelah data peramalan curah hujan tahun 2019 didapatkan, dilakukan analisa indeks kekeringan dan diperoleh indeks SPI bernilai negatif yang tertinggi terjadi pada bulan Januari yaitu $-0,252$, sedangkan SPI bernilai positif tertinggi terjadi pada bulan Juli yaitu sebesar 0,169. Indeks kekeringan di D.I Kelayang bersifat "Normal". Peramalan indeks kekeringan ini dapat menjadi informasi tambahan bagi Badan Nasional Penanggulangan Bencana.
\end{abstract}

Kata Kunci : Time Series, SARIMA, Indeks Kekeringan, SPI, D.I Kelayang

\begin{abstract}
Drought is one of the natural disasters that occur slowly lasting for a long time until the rainy season arrives which has a broad impact. One of the effects of drought in agriculture has occurred in the Indragiri Hulu district in 2015. The Kelayang irrigation area (D.I) is a potential irrigation area that irrigates agricultural areas in Indragiri Hulu Regency. To overcome the impact of drought for the future it is necessary to forecast the drought index. The drought index is very dependent on rainfall. For this reason, D.I Kelayang rainfall forecasting is done using the Seasonal Autogressive Integrated Moving Average (SARIMA) method because it is assumed that rainfall is data that contains seasonal patterns. Then the drought index analysis is done using the Standardized Precipitation Index (SPI) method. The results obtained by the SARIMA $(2,0,1)(0,1,1) 12$ model are suitable models for forecasting because they have passed the standardized residual and normality test with the mean squared of the smallest residual that is 4111.51. After the 2019 rainfall forecasting data was obtained, an analysis of the drought index was obtained and the highest SPI index was negative in January which was -0.252, while the highest positive SPI value occurred in July which was 0.169. The drought index in Kelayang D.I is "Normal". This drought index forecasting can be additional information for the National Disaster Management Agency.
\end{abstract}

Keywords: Time Series, SARIMA, Drought Index, SPI, Kelayang Irrigation Area

\section{PENDAhuluan}

Kekeringan adalah salah satu bencana alam yang terjadi secara perlahan berlangsung lama hingga musim hujan tiba yang mempunyai dampak yang luas. Kekeringan terjadi akibat adanya penyimpangan kondisi cuaca dari kondisi normal yang terjadi di suatu wilayah. Penyimpangan tersebut dapat berupa berkurangnya curah hujan dibandingkan dengan kondisi normal [1].

Di bidang pertanian, kekeringan selalu menjadi hal yang ditakuti oleh para petani karena mengganggu sistem produksi yang kemudian mengakibatkan kerugian. Berbeda dengan fenomena banjir, kekeringan cukup sulit diukur dan diprediksi karena terjadi sangat lambat. Salah satu faktor yang berpengaruh terhadap kegagalan produksi pertanian di Indonesia adalah kejadian ekstrem El-Nino dan La-Nina. Secara umum peristiwa El-Nino Southern Oscillation (ENSO berulang antara 2 hingga 7 tahun. Di Indonesia, peristiwa ENSO diidentikkan dengan musim kering yang melebihi kondisi normalnya. Hal ini berbanding terbalik dengan peristiwa La-Niña yang justru menghasilkan curah hujan melebihi batasan normalnya [2].

Indragiri Hulu merupakan salah satu kabupaten di Provinsi Riau yang pernah mengalami kekeringan lahan padi dan sawah seluas 273 hektare pada tahun 2015. Kemarau panjang menyebabkan warga kesulitan mendapatkan air bersih. Selain itu, banyak petani 
yang mengalami gagal panen. Indragiri Hulu memiliki beberapa daerah irigasi, salah satunya yang terbesar adalah D.I Kelayang yang merupakan salah satu daerah yang menjadi wewenang atau tanggung jawab Balai Wilayah Sungai Sumatera III di Provinsi Riau.

D.I Kelayang merupakan daerah irigasi potensial yang terletak pada $0^{0} 15^{\prime}$ Lintang Utara, $1^{0} 5^{\prime}$ Lintang Selatan, $101^{0} 10^{\prime}$ Bujur Timur, dan $102^{\circ} 48^{\prime}$ Bujur Barat. D.I Kelayang yang berlokasi di Kecamatan Rakit Kulim Kabupaten Indragiri Hulu, dengan target layanan yang luas sebesar 3003 Ha, berada di 3 Desa, yaitu Desa Kelayang, Desa Lubuk Setarak, dan Desa Patonggan. Sebagai upaya pemerintah dalam meningkatkan produksi pertanian dan memperlancar distribusi air irigasi persawahan warga setempat, maka pada tahun 2017 dilakukan rehabilitasi jaringan irigasi D.I Kelayang Kabupaten Indragiri Hulu. Tetapi pembangunan sarana dan prasarana irigasi saja belum cukup. Untuk kewaspadaan dan antisipasi terhadap bencana kekeringan yang akan datang diperlukan sebuah peramalan. Tingkat kekeringan suatu wilayah dipengaruhi oleh faktor curah hujan. Data curah hujan merupakan data deret waktu (time series). Peramalan data deret waktu dilakukan dengan mengidentifikasi pola-pola data historis masa lalu yang diambil secara berkala untuk membuat perkiraan masa depan [3]. Salah satu metode peramalan yang sering digunakan adalah metode Seasonal Autoregressive Integrated Moving Average (SARIMA).

SARIMA adalah salah satu metode deret waktu yang terdiri dari pola musiman atau Seasonal, Autoregressive (AR), Moving Average (MA) dan Integrated. Metode SARIMA ditulis dalam bentuk ( $, \mathrm{d}, \mathrm{q})(\mathrm{P}, \mathrm{D}, \mathrm{Q}) \mathrm{S}$. Orde p merupakan komponen Autoregressive yang digunakan untuk memodelkan autokorelasi yang terdapat pada deret waktu dengan melakukan regresi pada variabel lag sebesar p, orde d menyatakan orde differencing untuk membuat data yang tidak stasioner menjadi stasioner, orde $\mathrm{q}$ merupakan orde Moving Average untuk memodelkan lagged error sebanyak q, orde P merupakan orde Autoregressive musiman, $\mathrm{D}$ orde differencing pada periode musiman, dan Q adalah orde Moving Average musiman [4]. Metode SARIMA dikenal dengan metode ARIMA musiman yang dipelajari secara mendalam oleh George Box dan Gwilym Jenkins dan terdiri dari empat tahap yaitu identifikasi, estimasi, pemeriksaan diagnostik, dan peramalan [5].

Informasi mengenai potensi kekeringan sangat diperlukan untuk pencegahan ataupun penanggulangan untuk mengurangi dampak negatif yang ditimbulkan [6]. Dalam penelitian indeks kekeringan dan indeks ketajaman kekeringan ini yang digunakan adalah metode Standardized Precipitation Index (SPI). Metode ini merupakan model untuk mengukur kekurangan/defisit curah hujan pada berbagai periode berdasarkan kondisi normalnya. Kekeringan yang digunakan pada metode SPI adalah kekeringan meteorologis yang merupakan besaran curah hujan yang terjadi di bawah kondisi normal pada suatu musim. Perhitungan tingkat kekeringan merupakan indikasi pertama terjadinya kondisi kekeringan [7].

Berdasarkan hasil penelitian Darfia, dengan menggunakan data curah hujan dari tahun 1998 sampai tahun 2017, analisis dengan metode SPI menunjukkan hasil bahwa sifat kekeringan di D.I Kelayang adalah "Normal". Waktu-waktu yang harus mendapat perhatian lebih adalah bulan Juni hingga September karena pada bulan-bulan ini kekeringan menunjukkan sifat yang lebih kering dibandingkan bulan-bulan lainnya [8].

Berdasarkan latar belakang di atas, dilakukan penelitian tentang meramalkan curah hujan menggunakan metode SARIMA dan menganalisis indeks kekeringan dari hasil ramalan menggunakan metode SPI kemudian ditentukan tingkat kekeringan di D.I Kelayang Kabupaten Indragiri Hulu Provinsi Riau.

\section{METODOLOGI}

Dalam melakukan penelitian ini, peneliti berpedoman pada kerangka kerja penelitian yang dapat dilihat pada gambar 1 . 
Vol. 22, No. 1, Maret 2020

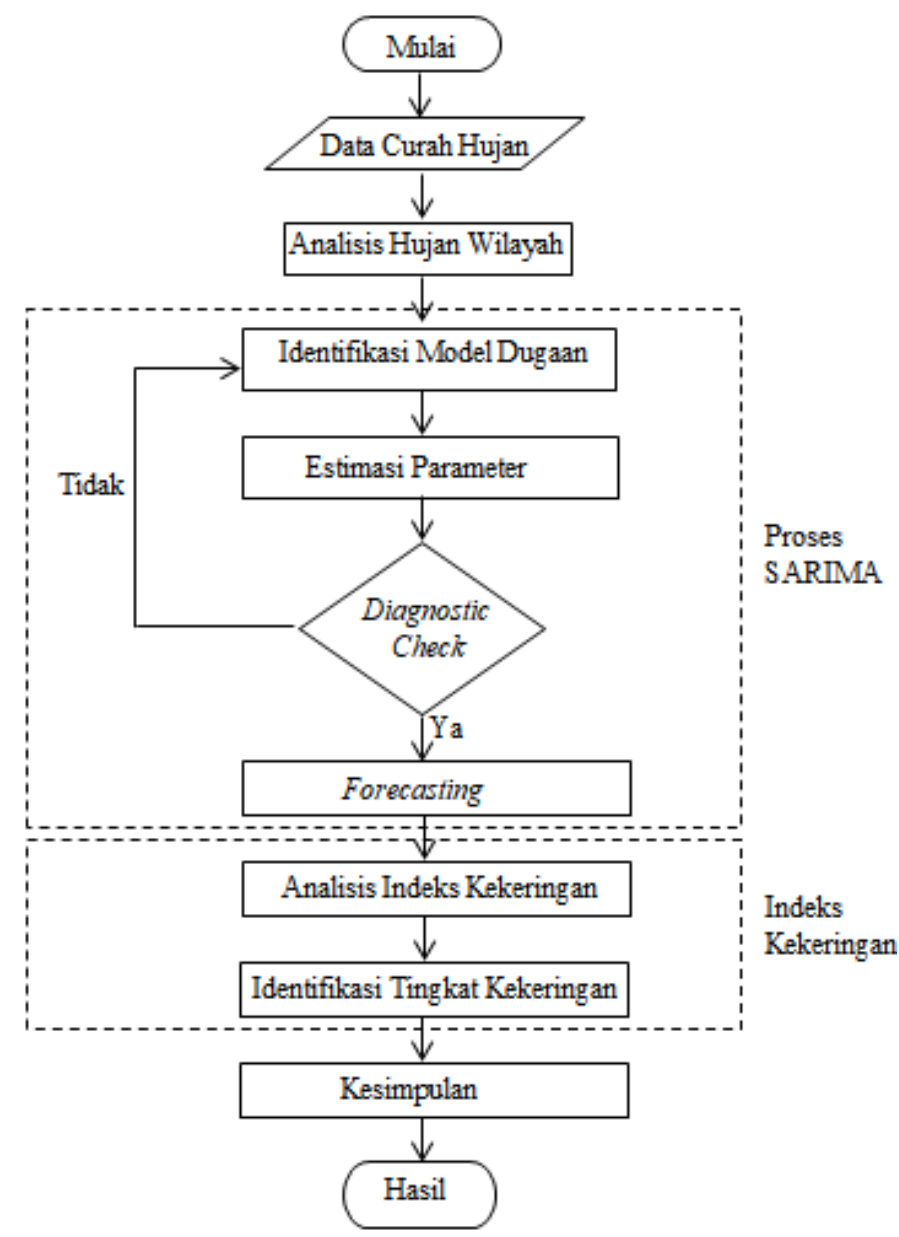

Gambar 1. Kerangka Penelitian

Data yang digunakan dalam memprediksi indeks kekeringan D.I Kelayang adalah data curah hujan harian yang diperoleh dari 4 stasiun hujan yang berada di sekitar D.I Kelayang yaitu stasiun hujan Air Molek, Lirik, Pangkalan Kasai, dan Talang Jerinjing. Berikut adalah gambar peta lokasi penelitian :

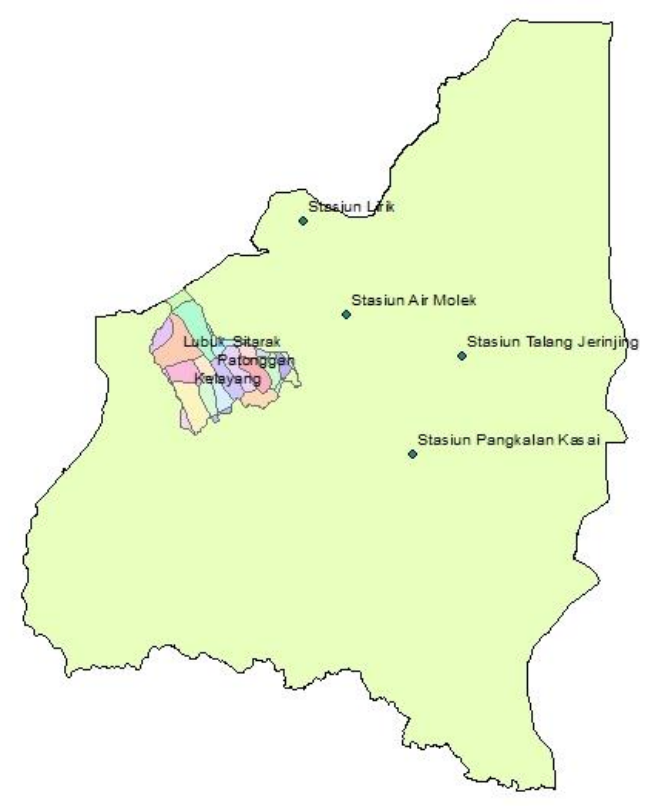

Gambar 2. Kabupaten Indragiri Hulu dengan D.I Kelayang dan 4 stasiun hujan disekitarnya 
Data dari keempat stasiun hujan tersebut merupakan data primer dari tahun 1998 sampai tahun 2018 yang diperoleh dari Balai Wilayah Sungai Sumatera III di Provinsi Riau.

Data yang sudah diperoleh diolah dalam tiga tahapan sesuai dengan Gambar 1 yaitu :

1. Analisis Hujan Wilayah

Data harian dari 4 stasiun hujan dijadikan data bulanan dengan cara dijumlahkan curah hujan hariannya. Setelah itu ditentukan hujan wilayahnya dengan metode aljabar yakni: mencari rata-rata curah hujan bulanan dari 4 stasiun hujan yang hasilnya disebut sebagai data hujan wilayah yang akan dijadikan input dalam peramalan.

2. Peramalan dengan SARIMA

Proses awal lakukan identifikasi model dengan memeriksa kestasioneran data dalam mean dan varians. Untuk memastikan bahwa data tersebut stasioner atau tidak terhadap mean dan varian dapat dilakukan dengan pemeriksaan. Pemeriksaan kestasioneran dalam varians dapat dilakukan dengan transformasi Box-Cox dan kestasioneran dalam mean dapat dilakukan dengan Augmented Dickey Fuller [9]. Apabila data tidak stasioner dalam varians dilakukan transformasi stabilitas varians, sedangkan data yang tidak stasioner dalam mean dilakukan proses differencing. Setelah data stasioner, dibuat model sementara dengan mengidentifikasi plot Autocorrelation Function (ACF) dan Partial Autocorrelation Function (PACF) untuk menentukan orde pada model. Langkah selanjutnya lakukan estimasi parameter-parameter AR, MA, musiman dan non-musiman dan uji signifikasi dari parameternya. Asumsi lain yang harus dipenuhi adalah error yang ada harus mengikuti proses white noise yaitu error tidak berautokorelasi dan berdistribusi normal. Uji yang dapat digunakan dalam melihat autokorelasi adalah uji Ljung-Box dan Uji Kolmogorov-Smirnov untuk melihat kenormalan [10]. Apabila terdapat beberapa model yang memenuhi semua asumsi, dilakukan seleksi untuk menentukan model terbaik berdasarkan residual (error) dengan memilih model yang memiliki nilai MS atau Means Square (cara untuk mengukur kesalahan, adalah rata-rata selisih kuadrat nilai yang diramalkan dan yang diamati) paling kecil [11].

SARIMA memiliki bentuk umum sebagai berikut [12]:

$$
\begin{gathered}
\left.\phi_{P}(B)-B\right)^{d}\left(1-B^{s}\right)^{D} X_{t} \\
\quad=\nabla_{q}\left(B^{\prime}\right) \Theta_{Q}\left(B^{s}\right) e_{t}
\end{gathered}
$$

dengan :

$\begin{array}{ll}e_{t} & \text { : error } \\ X_{t} & \text { : Nilai Pengamatan pada waktu ke- } \\ & \mathrm{t}(\mathrm{t}=1,2, \ldots, \mathrm{n}) \\ (1-B)^{d} & : \text { Operasi matematis dari } \\ & \text { differencing non musiman } \\ \left(1-B^{s}\right)^{D} & \text { : Operasi matematis dari } \\ & \text { differencing musiman } \\ \phi_{P}(B) & : \text { Operator Autoregressive }= \\ & \left(1-\phi_{1} B-\phi_{2} B^{2}-\cdots-\phi_{P} B^{P}\right) \\ \Phi_{P}\left(B^{s}\right) & : \text { Operator Autoregresive Musiman }= \\ & \left(1-\phi_{1} B^{s}-\phi_{2} B^{2 s}-\cdots-\phi_{P} B^{P s}\right) \\ \theta_{q}(B) & : \text { Operator Moving Average }= \\ & \left(1+\theta_{1} B-\theta_{2} B^{2}-\cdots-\theta_{q} B^{q}\right) \\ \Theta_{Q}\left(B^{s}\right) & : \text { Operator Moving Average Musiman } \\ & =\left(1-\Theta_{1} B^{s}-\Theta_{2} B^{2 s}-\cdots-\Theta_{Q} B^{Q s}\right)\end{array}$

3. Indeks kekeringan dengan metode SPI

Standardized Precipitation Index (SPI) merupakan indeks kekeringan yang dikembangkan oleh McKee et al. Pada rentang waktu yang singkat, SPI berkaitan erat dengan kelembaban tanah, sementara pada rentang waktu yang lebih panjang, SPI dapat dihubungkan dengan air tanah dan waduk. SPI dapat diterapkan di berbagai daerah dengan iklim yang sangat berbeda. Indeks ini menguantifikasi curah hujan sebagai data awal [13].

$$
=\frac{x_{i j}-x_{(r t) j}}{\sigma_{j}}
$$

dengan : 
$Z_{i j} \quad=$ nilai SPI tahun ke $\mathrm{i}$ bulan ke $\mathrm{j}$

$x_{i j}=$ hujan bulanan tahun ke $\mathrm{i}$ bulan ke $\mathrm{j}$

$x_{(r t) j}=$ hujan rata-rata bulan $\mathrm{j}$

$\sigma_{j} \quad=$ simpangan baku bulan $\mathrm{j}$

Tabel 1. Klasifikasi Skala Nilai SPI

\begin{tabular}{|l|l|}
\hline \multicolumn{1}{|c|}{ Nilai SPI } & \multicolumn{1}{c|}{ Kategori } \\
\hline$\geq 2.00$ & Ekstrim Basah \\
\hline $1.50-1.99$ & Sangat Basah \\
\hline $1.00-1.49$ & Basah \\
\hline$-0.99-0.99$ & Normal \\
\hline$-1.49--1.00$ & Kering \\
\hline$-1.99--1.5$ & Sangat Kering \\
\hline$\leq-2.00$ & Ekstrim Kering \\
\hline
\end{tabular}

Tahap awal dalam menghitung nilai SPI adalah menghitung selisih hujan sebenarnya dengan hujan rata-rata dengan menggunakan skala waktu tertentu, kemudian dibagi dengan simpangan baku (standar deviasi). Tahap kedua yaitu mentransformasikan data hujan bulanan tersebut yang bertujuan untuk menghilangkan faktor musim serta membentuk suatu deret yang sama dengan distribusi probabilitas yang sama. Proses transformasi ini yaitu mengubah data hujan bulanan menjadi bentuk fungsi peluang kumulatif melalui distribusi gamma. Perhitungan SPI melibatkan kecocokan fungsi kepadatan probabilitas gamma untuk distribusi frekuensi tertentu dari total curah hujan untuk setiap stasiun hujan. Parameter alpha dan beta dari fungsi kepadatan probabilitas gamma diperkirakan untuk setiap stasiun hujan, untuk setiap skala waktu yang ditinjau, dan untuk setiap bulan dalam setahun. Pada penelitian ini skala waktu yang digunakan adalah 1 bulan (SPI-1).

\section{HASIL DAN PEMBAHASAN}

\subsection{Analisis Hujan Wilayah}

Data yang digunakan dalam memprediksi indeks kekeringan D.I Kelayang adalah data bulanan hujan kawasan mulai dari tahun 1998 sampai tahun 2018 yang berjumlah 252 data. Data tersebut adalah data harian 4 stasiun hujan ini diolah menjadi data bulanan dan dijadikan hujan kawasan D.I Kelayang dengan metode aljabar sehingga diperoleh data hujan wilayah pada tabel 2.

Tabel 2. Data Hujan Wilayah Kelayang

\begin{tabular}{|c|c|c|c|c|c|c|c|c|c|c|c|c|}
\hline Tahun & Jan & Feb & Mar & Apr & Mei & Jun & Jul & Agu & Sep & Okt & Nov & Des \\
\hline 1998 & 118,55 & 133,50 & 164,48 & 145,43 & 138,83 & 175,00 & 144,48 & 230,70 & 209,58 & 136,90 & 88,03 & 194,25 \\
\hline 1999 & 186,25 & 127,63 & 285,40 & 112,48 & 136,88 & 92,90 & 114,83 & 185,68 & 133,98 & 298,05 & 229,78 & 203,75 \\
\hline 2000 & 264,50 & 153,23 & 140,65 & 310,75 & 190,05 & 156,58 & 91,93 & 156,68 & 176,00 & 176,13 & 237,40 & 287,68 \\
\hline 2001 & 239,58 & 161,40 & 181,58 & 219,78 & 151,65 & 92,03 & 111,63 & 189,05 & 133,83 & 264,90 & 385,75 & 243,18 \\
\hline 2002 & 300,65 & 92,63 & 264,00 & 231,28 & 167,73 & 124,43 & 111,93 & 67,03 & 159,68 & 183,10 & 409,73 & 375,85 \\
\hline 2003 & 264,98 & 233,55 & 298,10 & 352,15 & 154,63 & 70,73 & 128,40 & 113,43 & 162,08 & 329,75 & 273,70 & 315,05 \\
\hline 2004 & 261,43 & 171,35 & 251,35 & 200,40 & 159,80 & 117,85 & 223,90 & 94,30 & 224,30 & 276,30 & 294,15 & 298,23 \\
\hline 2005 & 136,53 & 77,93 & 151,65 & 249,20 & 284,60 & 99,80 & 146,85 & 170,35 & 239,65 & 266,23 & 286,50 & 240,48 \\
\hline 2007 & 203,95 & 174,75 & 171,83 & 243,78 & 258,80 & 101,15 & 139,05 & 115,55 & 202,70 & 166,93 & 264,83 & 211,85 \\
\hline 2008 & 228,08 & 146,17 & 336,50 & 269,17 & 120,92 & 120,58 & 56,33 & 253,58 & 224,00 & 198,58 & 268,35 & 134,83 \\
\hline 2009 & 139,05 & 126,60 & 364,20 & 195,58 & 139,95 & 75,18 & 53,13 & 85,83 & 183,60 & 223,95 & 331,63 & 372,30 \\
\hline 2010 & 249,25 & 204,67 & 205,17 & 355,58 & 85,00 & 177,50 & 370,17 & 310,92 & 192,75 & 299,25 & 415,00 & 187,58 \\
\hline 2011 & 237,58 & 130,33 & 148,33 & 322,45 & 153,53 & 183,35 & 126,38 & 136,63 & 148,65 & 228,23 & 234,88 & 158,13 \\
\hline 2012 & 119,92 & 155,60 & 183,86 & 355,01 & 186,42 & 34,84 & 130,18 & 82,19 & 180,39 & 225,23 & 425,22 & 236,03 \\
\hline 2013 & 75,48 & 101,28 & 110,58 & 123,85 & 173,08 & 72,20 & 72,55 & 70,38 & 96,95 & 125,70 & 216,73 & 190,08 \\
\hline 2014 & 103,93 & 60,18 & 93,95 & 59,15 & 65,75 & 22,88 & 34,60 & 84,05 & 90,40 & 120,93 & 185,50 & 115,63 \\
\hline 2016 & 118,18 & 86,15 & 149,30 & 138,10 & 114,38 & 31,70 & 86,40 & 48,93 & 54,30 & 125,88 & 144,75 & 73,60 \\
\hline 2017 & 130,75 & 197,93 & 191,93 & 264,30 & 224,33 & 107,13 & 213,75 & 128,13 & 239,38 & 123,10 & 320,40 & 165,75 \\
\hline 2018 & 110,25 & 161,00 & 205,73 & 193,15 & 191,13 & 135,25 & 76,28 & 96,80 & 57,55 & 253,03 & 342,38 & 174,88 \\
\hline
\end{tabular}

Tabel 2 menunjukkan bahwa curah hujan terbesar yakni 446,03 mm terjadi pada bulan April 2006 dan curah hujan terendah 22,88 mm terjadi pada bulan Juni 2014.

\subsection{Peramalan}


Data curah hujan merupakan data deret waktu (time series). Peramalan data deret waktu dilakukan dengan mengidentifikasi polapola data historis masa lalu yang diambil secara berkala untuk membuat perkiraan di masa depan. Berdasarkan data hujan kawasan dari tahun 1998-2018, diketahui bahwa data tersebut mengandung pola musiman. Pola musiman dipengaruhi oleh faktor musiman yang terjadi secara berulang. Dengan demikian dapat digunakan model Seasonal Autoregressive Integrated Moving Average (SARIMA) untuk meramalkan curah hujan wilayah yang akan datang yang digunakan untuk menghitung indeks kekeringan di daerah Kelayang. Data hujan tersebut diolah melalui empat tahap yaitu identifikasi model, estimasi parameter, pemeriksaan diagnostik, dan peramalan. Sebelum mengidentifikasi model, kita harus memastikan dulu bahwa data telah stasioner.

\section{Kestasioneran}

Uji pola data merupakan kegiatan menganalisis pola pergerakan data curah hujan wilayah. Pola data menggambarkan karakteristik data dalam suatu periode. Gambar 3 merupakan grafik curah hujan wilayah Kelayang Januari 1998 sampai Desember 2018.

Berdasarkan Gambar 3, dapat dikatakan bahwa data tersebut mengandung pola musiman yang terus berulang setiap tahun, oleh sebab itu metode yang digunakan dalam melakukan forecast terhadap data tersebut adalah metode SARIMA. Data curah hujan wilayah Kelayang terlihat stasioner terhadap mean, tetapi tidak stasioner terhadap varian. Stasioner dalam mean dapat dilihat pada plot data time series yang terlihat berfluktuasi di sekitar garis yang sejajar sumbu waktu. Untuk lebih lanjut, kita dapat melihat plot ACF dan PACF dari data curah hujan wilayah Kelayang pada Gambar 4.

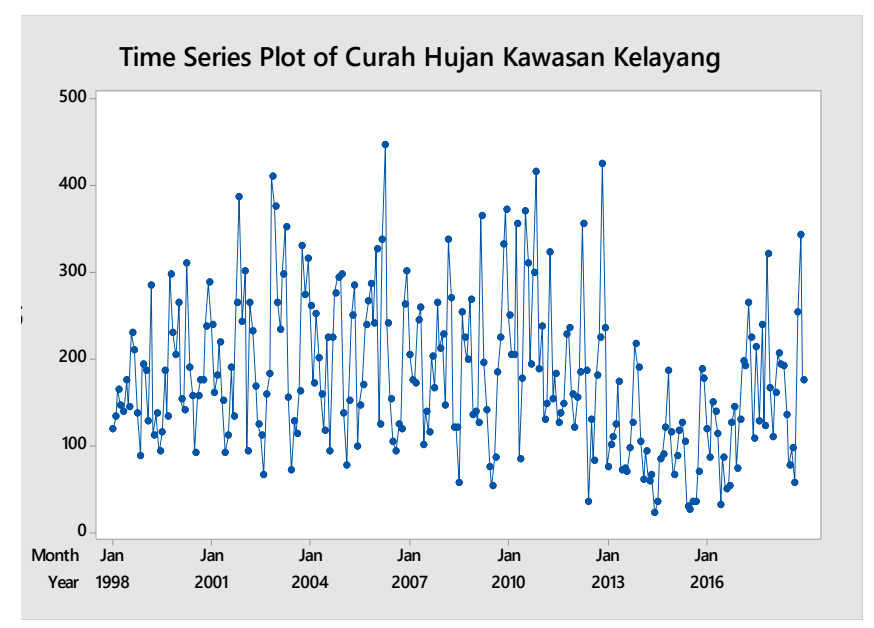

Gambar 3. Plot Data Curah Hujan Wilayah

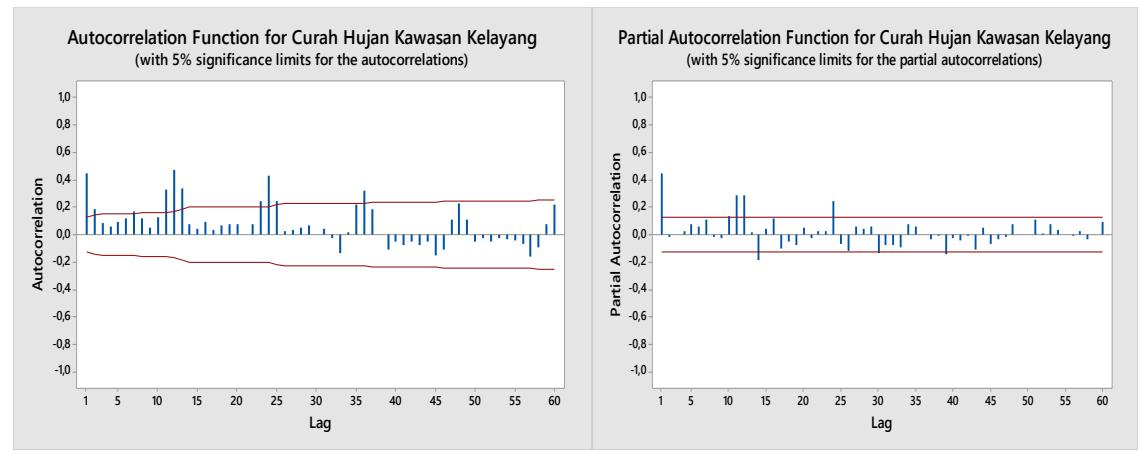

Gambar 4. Plot ACF dan PACF

Grafik ACF dan PACF pada Gambar 4 menunjukkan bahwa data sudah stasioner terhadap mean karena lag-lag pada ACF turun secara eksponensial pada lag 2. Karena data tidak mengalami pola kenaikan ataupun penurunan, maka tidak perlu dilakukan differencing nonseasonal sehingga $\mathrm{d}=0$. Tetapi, lag-lag pada $\mathrm{ACF}$ mengindikasikan adanya unsur pola seasonal pada data ditandai dengan lag-lag ACF yang membentuk pola gelombang. Untuk menghilangkan ketidakstasioneran data yang diakibatkan oleh pola seasonal dilakukan differencing seasonal sehingga orde $\mathrm{D}=1$. 
Plot data tidak stasioner terhadap varian dapat dilihat dari simpangan data yang besar atau variannya dipengaruhi oleh deret waktu atau konstan. Untuk memastikan data tidak stasioner terhadap varian dapat dilakukan pemeriksaan dengan transformasi Box-Cox. Hasil pemeriksaan dapat dilihat pada Gambar 5.

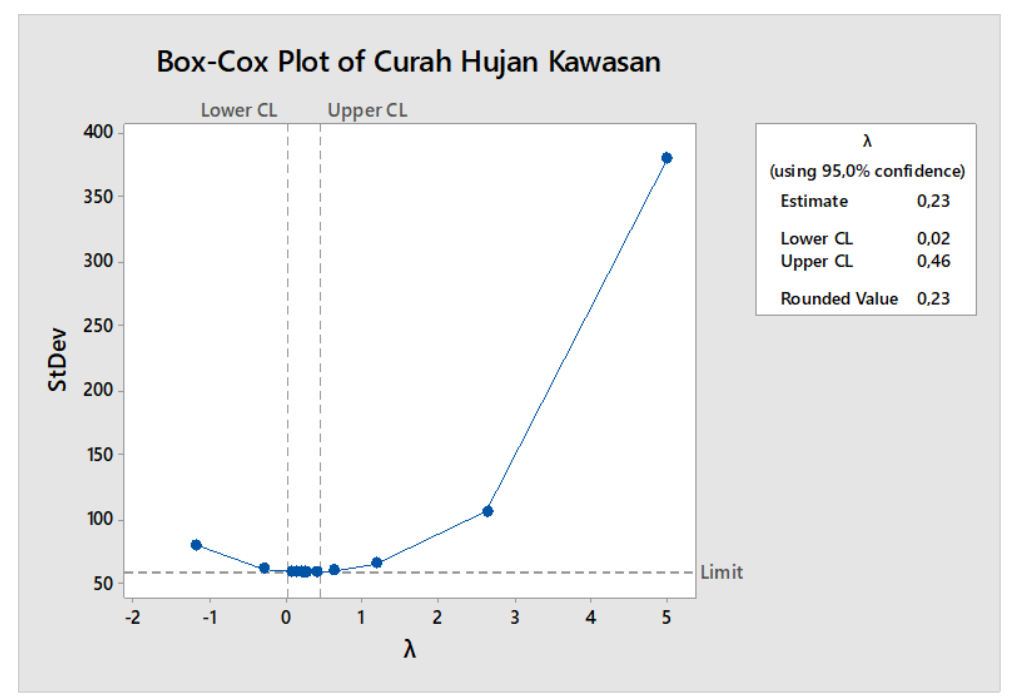

Gambar 5. Box-Cox Plot

Pada Gambar 5 dapat dilihat bahwa Rounded Value adalah 0,23 yang berarti data belum stasioner terhadap varians sehingga perlu dilakukan transformasi data sampai diperoleh Rounded Value $=1$. Setelah data stasioner terhadap varians maka dilanjutkan dengan uji kestasioneran dalam mean dengan Augmented Dickey Fuller. Hasil uji menunjukkan nilai ADF test statistic = $|-8,597648|>|-2,873440|$ pada nilai kritis $5 \%$ dengan probability $=0,0000$. Hal ini menunjukkan bahwa data sudah stasioner terhadap mean.

\section{Identifikasi Model}

Data sudah stasioner terhadap mean dengan melakukan differencing seasonal dan stasioner terhadap varians dengan melakukan transformasi data dapat dilihat grafiknya pada Gambar 6.

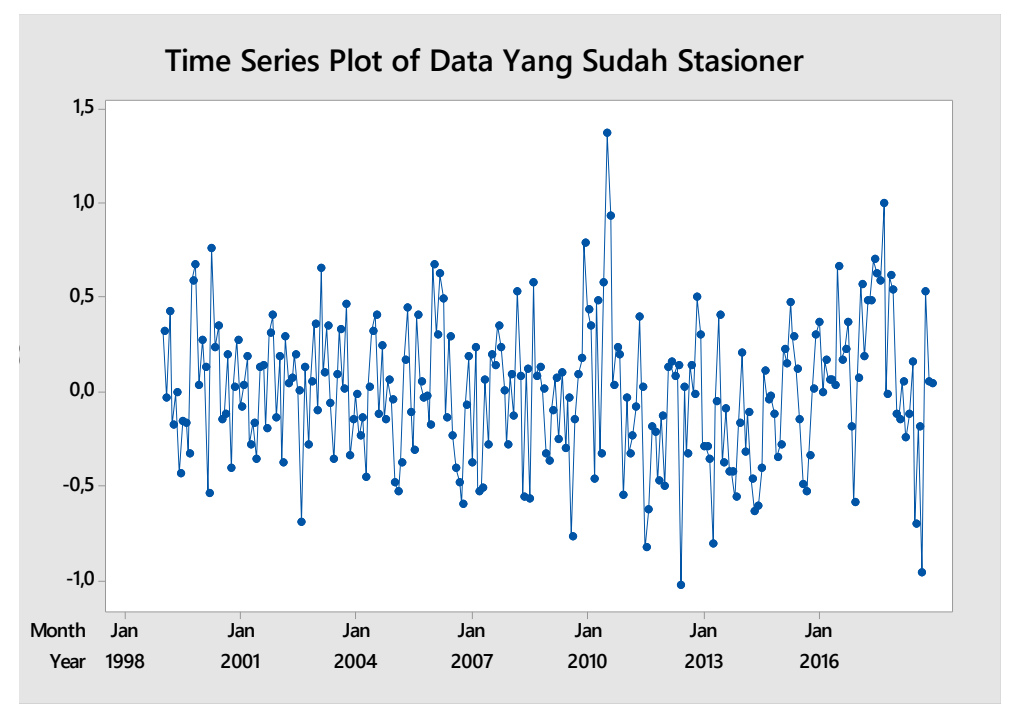

Gambar 6. Plot Data Stasioner

Pada Gambar 6 dapat dilihat bahwa data berfluktuasi sepanjang sumbu waktu dan memiliki simpangan atau varian yang tidak terlalu besar sehingga dapat disimpulkan bahwa data sudah stasioner. Setelah data stasioner, maka tahapan selanjutnya adalah menentukan model sementara dengan melihat plot ACF dan PACF pada data yang sudah stasioner. Plot ACF digunakan untuk 
menentukan orde Moving Average (q) dan Moving Average musiman (Q). Plot PACF digunakan untuk menentukan orde Autoregressive (p) dan Autoregressive musiman (P).

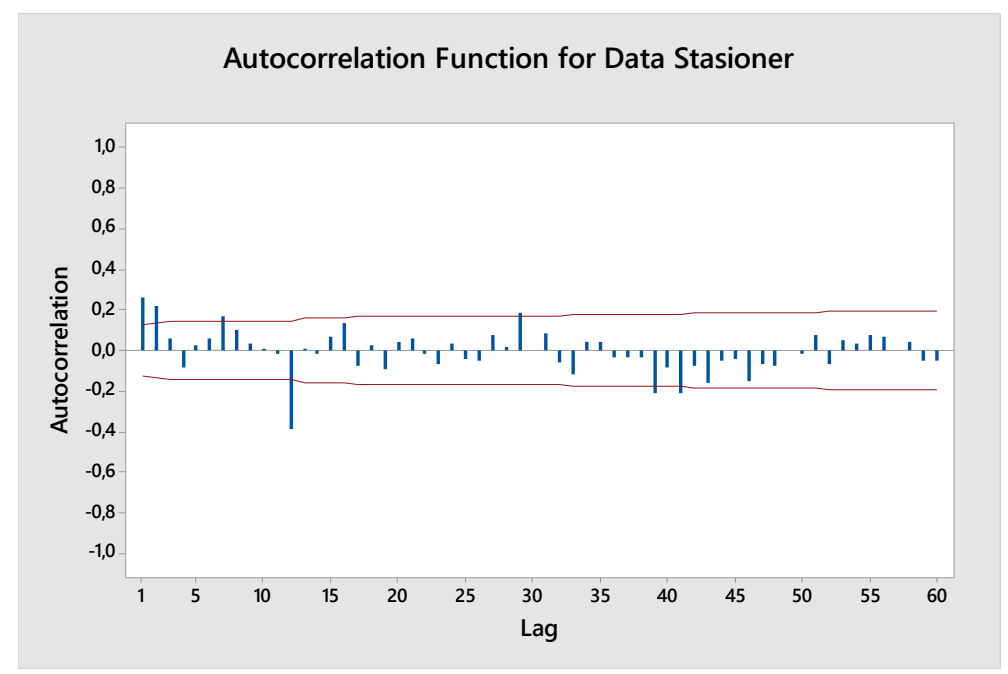

Gambar 7. Plot ACF

Berdasarkan Gambar 7, plot ACF terlihat cutt off pada lag 1, lag 2 dan lag 12(lag 1 musiman) sehingga orde Moving Average yang mungkin adalah $\mathrm{q}=1, \mathrm{q}=2$ dan $\mathrm{Q}=1$.

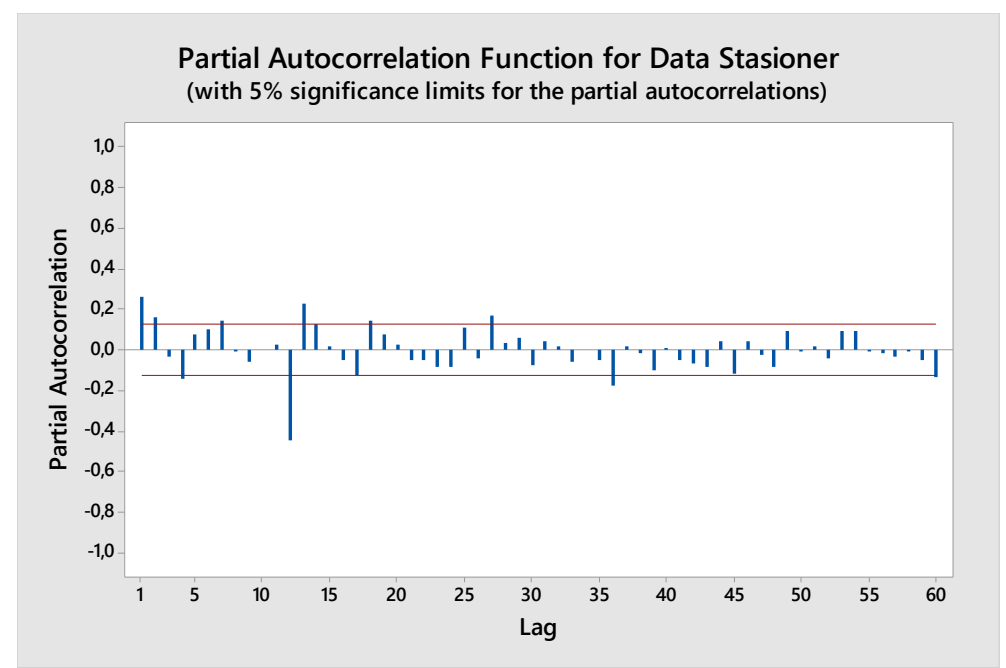

Gambar 8. Plot PACF

Berdasarkan Gambar 8, plot PACF terlihat cutt of pada lag 1, lag 2, lag 4, dan lag 12 (lag 1 musiman) sehingga orde Autoregressive yang mungkin adalah $\mathrm{p}=2$ dan $\mathrm{P}=1$. Selanjutnya dapat disimpulkan bahwa model sementara yang mungkin adalah SARIMA $(0,0,1)(0,1,1)^{12}, \quad \operatorname{SARIMA}(1,0,0)(0,1,1)^{12}, \quad \operatorname{SARIMA}(1,0,1)(0,1,1)^{12}, \quad \operatorname{SARIMA}(2,0,0)(0,1,1)^{12}$, SARIMA $(0,0,2)(0,1,1)^{12}, \quad \operatorname{SARIMA}(2,0,2)(0,1,1)^{12}, \quad \operatorname{SARIMA}(2,0,1)(0,1,1)^{12}, \quad \operatorname{SARIMA}(1,0,2)(0,1,1)^{7}, \quad$ dan $\operatorname{SARIMA}(4,0,0)(0,1,1)^{12}$

\section{Estimasi Parameter}

Setelah menetapkan model sementara, dilakukan estimasi pada parameter AR dan MA, musiman dan non musiman dengan menggunakan metode kuadrat terkecil atau ordinary least square. Model yang baik adalah model yang menunjukkan estimasi parameter-parameter yang signifikan berbeda dengan nol. Hasil estimasi parameter (uji signifikansi) dapat dilihat pada Tabel 3. 
Tabel 3. Tabel Uji Signifikansi

\begin{tabular}{|c|c|c|}
\hline No & Model & Uji Signifikansi \\
\hline 1 & SARIMA $(0,0,1)(0,1,1)^{12}$ & Signifikan \\
\hline 2 & $\operatorname{SARIMA}(1,0,0)(0,1,1)^{12}$ & Signifikan \\
\hline 3 & $\operatorname{SARIMA}(1,0,1)(0,1,1)^{12}$ & Signifikan \\
\hline 4 & $\operatorname{SARIMA}(2,0,0)(0,1,1)^{12}$ & Signifikan \\
\hline 5 & $\operatorname{SARIMA}(0,0,2)(0,1,1)^{12}$ & Signifikan \\
\hline 6 & $\operatorname{SARIMA}(2,0,2)(0,1,1)^{12}$ & Tidak Signifikan \\
\hline 7 & $\operatorname{SARIMA}(2,0,1)(0,1,1)^{12}$ & Signifikan \\
\hline 8 & $\operatorname{SARIMA}(1,0,2)(0,1,1)^{12}$ & Tidak Signifikan \\
\hline 9 & SARIMA $(4,0,0)(0,1,1)^{12}$ & Tidak Signifikan \\
\hline
\end{tabular}

Pada Tabel 3 dapat dilihat bahwa model-model yang mempunyai parameter-parameter yang signifikan berbeda dengan nol adalah $\quad \operatorname{SARIMA}(0,0,1)(0,1,1)^{12}, \quad \operatorname{SARIMA}(1,0,0)(0,1,1)^{12}, \quad \operatorname{SARIMA}(1,0,1)(0,1,1)^{12}, \quad \operatorname{SARIMA}(2,0,0)(0,1,1)^{12}$, $\operatorname{SARIMA}(0,0,2)(0,1,1)^{12}$, dan $\operatorname{SARIMA}(2,0,1)(0,1,1)^{12}$. Sehingga untuk tahapan selanjutnya model-model tersebut dapat digunakan.

\section{Verifikasi (Diagnostic Check) Model}

Hal yang dilakukan pada tahapan ini yaitu melihat apakah model yang dihasilkan sudah layak digunakan untuk peramalan atau belum, dengan melihat residual yang dihasilkan model. Uji yang dilakukan adalah uji kerandoman residual dan uji kenormalan residual. Uji kerandoman residual dilakukan dengan menggunakan L-Jung Box. Dari 6 model yang memenuhi pada tahap estimasi, hanya 2 model yang memiliki nilai $P$-Value $>0,05$ pada setiap lagnya pada output L-Jung Box yakni :

Tabel 4. Output L-Jung Box

\begin{tabular}{|c|c|c|}
\hline \multirow{2}{*}{ Lag } & \multicolumn{2}{|c|}{$\boldsymbol{P}$-Value } \\
\cline { 2 - 3 } & SARIMA(1,0,1)(0,1,1) $)^{\mathbf{1 2}}$ & SARIMA $(\mathbf{2 , 0 , 1})(\mathbf{0 , 1 , 1})^{\mathbf{1 2}}$ \\
\hline 12 & 0,134 & 0,320 \\
\hline 24 & 0,426 & 0,539 \\
\hline 36 & 0,162 & 0,180 \\
\hline 48 & 0,153 & 0,094 \\
\hline
\end{tabular}

Sedangkan untuk Uji kenormalan residual dapat dilihat pada Gambar 9 dan Gambar 10.

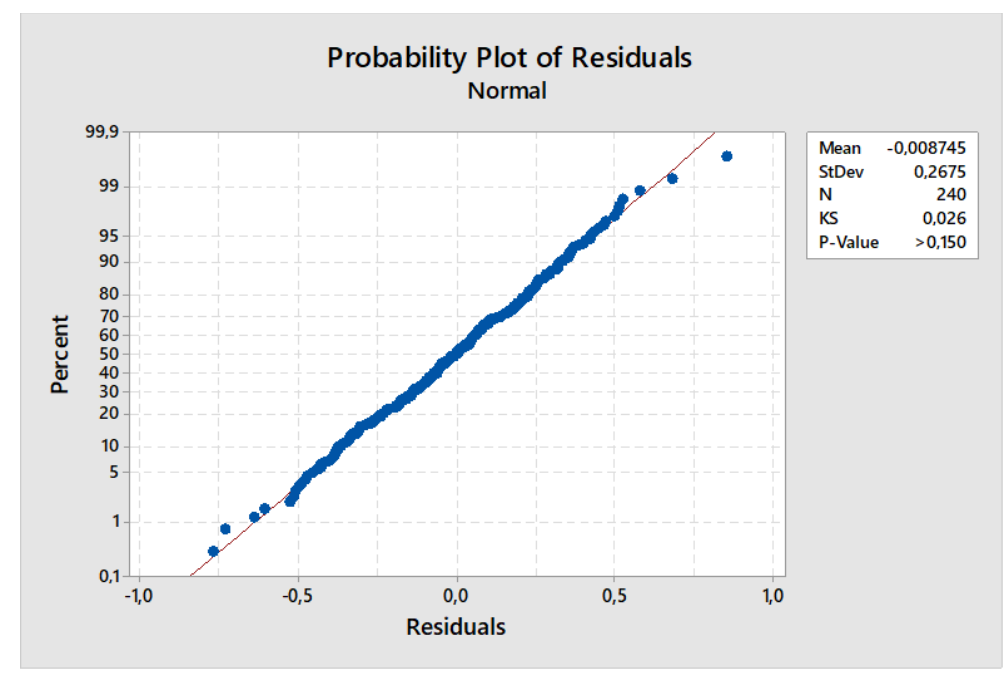

Gambar 9. Plot Residual Model SARIMA $(1,0,1)(0,1,1)^{12}$ 


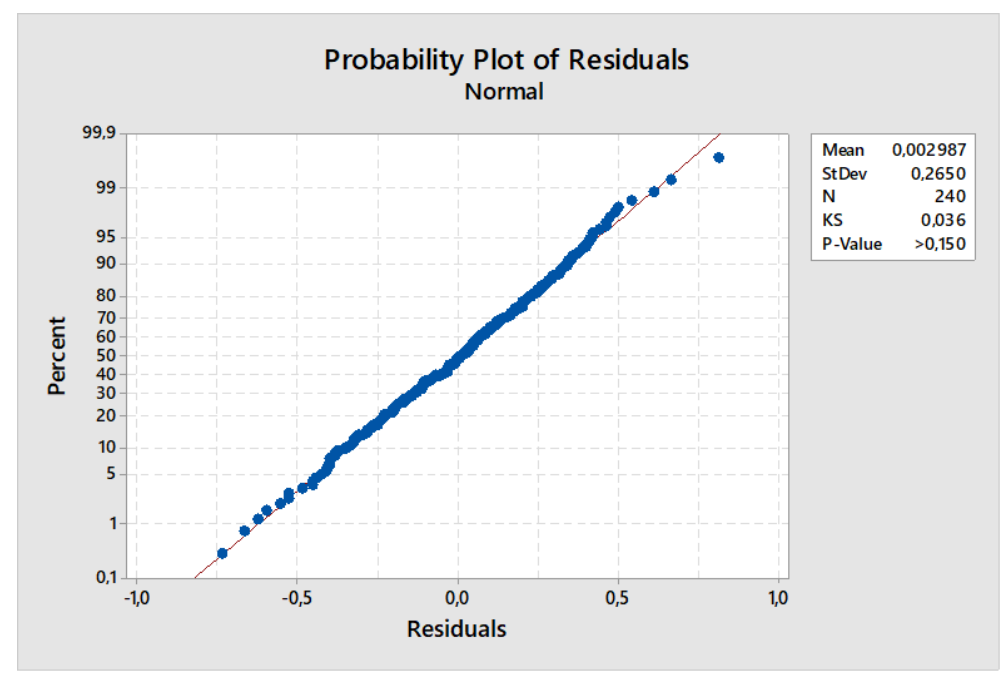

Gambar 10. Plot Residual Model SARIMA $(2,0,1)(0,1,1)^{12}$

Pada Gambar 9 dan 10 dapat dilihat bahwa kedua model mempunyai sebaran data residual yang normal yang dapat dilihat dari sebaran titik-titik biru yang menyebar sepanjang garis normal dan juga nilai $p$-value $>0,05$.

\section{Peramalan}

Setelah melewati berbagai tahap dalam metode SARIMA, didapatkan beberapa model yang cocok untuk digunakan dalam peramalan. Selanjutnya model-model yang cocok dievaluasi berdasarkan Mean Square (MS) of residual yang dapat dilihat pada Tabel 5.

Tabel 5. Mean Square (MS) of residual

\begin{tabular}{|c|c|}
\hline MODEL & MS (Mean Squared) \\
\hline SARIMA $(1,0,1)(0,1,1)^{12}$ & 4135,36 \\
\hline SARIMA $(2,0,1)(0,1,1)^{12}$ & 4111,51 \\
\hline
\end{tabular}

Pada Tabel 5 dapat dilihat bahwa model SARIMA $(2,0,1)(0,1,1)^{12}$ memiliki Mean Square $(M S)$ dari residual yang terkecil sehingga model tersebut dipilih untuk digunakan dalam peramalan.

Hasil peramalan curah hujan wilayah untuk 12 periode ke depan untuk tahun 2019 dan data observasi tahun 2019 dapat dilihat pada Tabel 6.

Tabel 6. Hasil Peramalan Curah Hujan Wilayah Kelayang Menggunakan Model SARIMA $(2,0,1)(0,1,1)^{12}$

\begin{tabular}{|c|c|c|}
\hline Bulan & Hasil Ramalan & Data Observasi \\
\hline Jan-19 & 158,51 & 274,5 \\
\hline Feb-19 & 136,77 & 276,75 \\
\hline Mar-19 & 194,39 & 248,55 \\
\hline Apr-19 & 223,21 & 275,95 \\
\hline Mei-19 & 161,25 & 133,75 \\
\hline Jun-19 & 95,17 & 169 \\
\hline Jul-19 & 117,45 & 50,875 \\
\hline Agt-19 & 116,90 & 63,125 \\
\hline Sep-19 & 142,13 & 77,875 \\
\hline Okt-19 & 183,81 & 161 \\
\hline Nov-19 & 272,08 & 119,5 \\
\hline Des-19 & 197,43 & 142,5 \\
\hline
\end{tabular}




\subsection{Indeks Kekeringan Dengan Metode SPI}

Setelah didapatkan peramalan data curah hujan wilayah D.I Kelayang tahun 2019, kemudian dilakukan penghitungan indeks kekeringannya berdasarkan data historis curah hujan wilayah dari tahun 1998 sampai 2018 dan hasil ramalan tahun 2019 dengan metode SPI.

Tabel 7. Indeks Kekeringan dan Sifat Kekeringan D.I Kelayang

\begin{tabular}{|c|c|c|}
\hline BULAN & $\begin{array}{c}\text { INDEKS } \\
\text { KEKERINGAN }\end{array}$ & $\begin{array}{c}\text { SIFAT } \\
\text { KEKERINGAN }\end{array}$ \\
\hline Jan-19 & $-0,232$ & Normal \\
\hline Feb-19 & 0,057 & Normal \\
\hline Mar-19 & $-0,006$ & Normal \\
\hline Apr-19 & $-0,094$ & Normal \\
\hline Mei-19 & 0,020 & Normal \\
\hline Jun-19 & 0,057 & Normal \\
\hline Jul-19 & 0,169 & Normal \\
\hline Agt-19 & 0,101 & Normal \\
\hline Sep-19 & $-0,052$ & Normal \\
\hline Okt-19 & $-0,087$ & Normal \\
\hline Nov-19 & $-0,112$ & Normal \\
\hline Des-19 & $-0,199$ & Normal \\
\hline
\end{tabular}

Dari tabel 7 dapat dilihat bahwa nilai indeks kekeringan pada tahun 2019 yang dianalisis menggunakan data peramalan (forecast) dari data hujan histori di D.I Kelayang berkisar antara -0,232 (Januari) sampai 0,169 (Juli) yang bersifat "Normal".

Dari 7 (tujuh) skala sifat kekeringan yaitu ekstrem basah, basah, sangat basah, normal, kering, sangat kering, dan ekstrem kering, indeks kekeringan SPI di D.I Kelayang hanya mengalami 1 (satu) skala sifat yakni "Normal".

\section{KESIMPULAN}

Model SARIMA $(2,0,1)(0,1,1)^{12}$ layak digunakan dalam peramalan curah hujan wilayah D.I Kelayang karena estimasi setiap parameternya secara signifikan berbeda dengan nol, memenuhi pemeriksaan diagnostic dimana residual dari model bersifat acak dan terdistribusi normal, dan memiliki nilai mean squared 4111,51.

Nilai indeks kekeringan pada tahun 2019 yang dianalisis menggunakan data peramalan (forecast) dari data hujan histori di D.I Kelayang bersifat "Normal". Indeks SPI bernilai negatif yang tertinggi terjadi pada bulan Januari yaitu -0,232 dan SPI bernilai positif tertinggi terjadi pada bulan Juli yaitu sebesar 0,169 .

Peramalan indeks kekeringan ini diharapkan dapat menjadi referensi bagi pemerintah terutama Badan Nasional Penanggulangan Bencana (BNPB) dalam mengantisipasi dampak kekeringan pada periode yang akan datang. Selain itu, diharapkan peneliti lain dapat menggunakan metode peramalan lainnya sebagai perbandingan.

\section{UCAPAN TERIMA KASIH}

Peneliti sangat berterima kasih kepada Balai Wilayah Sungai Sumatra III Provinsi Riau karena telah membantu terkait data penelitian.

\section{DAFTAR PUSTAKA}

[1] Mujtahiddin dan M. Iid, 2014, “Analisis Spasial Indeks Kekeringan Kabupaten Indramayu Spatial Analysis Of Drought Index In District Indramayu,” J. Meteorologi Dan Geofisika, vol. 15, no. 2, pp.99-107, 2014.

[2] E. Hermawan, V. Juniarti, Trismidianto, Krismianto, F. Ibnu, dan S. Ining, "Pengembangan ekspert sistem berbasis indeks ENSO, DMI, MONSUN, dan MJO Untuk Penentuan Awal Musim," Prosiding Pertemuan Ilmiah XXIV HFI Jateng \& DIY, Semarang, 2010. 
[3] W. Rahmalina, Sukri, "Peramalan Jumlah Kunjungan Wisatawan Pulau Cinta Menggunakan Metode ARIMA,” Prosiding Seminar Nasional Sains dan Teknologi, Pekanbaru, 2018.

[4] A. Supriatna, B. Subartini, E. Hertini, Riaman, "Prediksi Wisatawan Mancanegara Ke Jawa Barat Melalui Pintu Masuk Bandara Husein Sastranegara dan Pelabuhan Muarajati Menggunakan Metode SARIMA, "8th Industrial Research Workshop and National Seminar Politeknik Negeri Bandung July 26 - 27, 2017.

[5] S. Makridakis, S.C. Wheelwright and R.J. Hyndman, "Forecasting: methods and applications," JohnWiley \& Sons: New York, 1998.

[6] T. Aprilliyanti dan M. Zainuddin, "Pemetaan Potensi Kekeringan Lahan se-pulau Batam menggunakan Teknik Sistem Informasi Geografis (SIG) dan Penginderaan Jauh.," Majalah Geografi Indonesia, vol. 31, no.1, pp.91-94, 2017.

[7] D. Utami, R. R. Hadiani, S. Susilowati, "Prediksi Kekeringan Berdasarkan Standardized Precipitation Index (SPI) Pada Daerah Aliran Sungai Keduang Di Kabupaten Wonogiri,” J. Matriks Teknik Sipil, vol.1, no.3, pp.221-226, 2013.

[8] N.E. Darfia, W. Rahmalina, “Analisis Indeks Kekeringan Di Daerah Irigasi Kelayang Kabupaten Indragiri Hulu Provinsi Riau," J. Infrastruktur, vol.5 no. 1, pp.35-44, 2019

[9] R.A. Yaffee and M. McGee, “An introduction to time series analysis and forecasting: with applications of SAS® and SPSS®," Elsevier, 2000.

[10] N. Lestari dan N. Wahyuningsih, "Peramalan Kunjungan Wisatawan dengan Pendekatan Model SARIMA (Studi Kasus: Kusuma Argo Wisata)," J. Sains dan Seni ITS, vol 1, no.1, pp.29-33, 2012.

[11] Hadijah, "Peramalan Operasional Reservasi Dengan Program Minitab Menggunakan Pendekatan Arima Pt Surindo Andalan," J. The WINNERS, vol. 14, no. 1, pp.13-19, 2013.

[12] M. Ibrahim, M. Jamil, S. Akbar, A.M. Akhtar, Z.H. Mir, A.B. Imran, and A.J. Akhtar, "The fitting of SARIMA model on peads patients coming at outpatients medical laboratory (OPML), Mayo hospital, Lahore," JUMDC, vol.7, no.1, pp.1218, 2016.

[13] N.E. Darfia, M.S.B. Kusuma, dan A.A. Kuntoro, "Analisis Indeks Kekeringan di DAS Rokan Provinsi Riau Menggunakan Data CFSR,” J. Rab Construction Research, vol.1, no 2, pp.120-134, 2016. 